\title{
Mutations in the epidermal growth factor receptor (EGFR) gene in triple negative breast cancer: possible implications for targeted therapy
}

\author{
Yvonne Hui-Fang Teng ${ }^{1}$, Wai-Jin Tan ${ }^{1}$, Aye-Aye Thike ${ }^{1}$, Poh-Yian Cheok', Gary Man-Kit Tse ${ }^{2}$, Nan-Soon Wong ${ }^{3}$,
} George Wai-Cheong Yip ${ }^{4}$, Boon-Huat Bay ${ }^{4}$ and Puay-Hoon Tan ${ }^{*}$

\begin{abstract}
Introduction: Triple negative breast cancer is associated with poorer prognosis and unresponsiveness to endocrine and anti-HER2 directed agents. Despite emerging data supporting the use of polyADP-ribose polymerase (PARP) inhibitors, complete and durable responses are rare and exploration of additional targeted therapies is needed. Epidermal growth factor receptor (EGFR) is expressed in triple negative breast cancer and several clinical trials are testing the role of anti-EGFR directed therapy. However, the rate of EGFR mutations is poorly defined. We, therefore, sought to characterize EGFR mutations in triple negative breast cancers.
\end{abstract}

Methods: Seventy samples were randomly chosen from a cohort of 653 triple negative breast tumours for EGFR mutation analysis. These samples were immunostained for EGFR protein expression and consisted of negatively stained and positively stained cases. DNA was extracted from paraffin blocks and polymerase chain reaction was performed to amplify exon regions 18 to 21 of the EGFR gene. Direct sequencing of the purified PCR products was performed.

Results: EGFR mutations were found in 8 of 70 samples (11.4\%). Mutations were predominantly exon 19 deletions (4 of 70 samples, 5.7\%), which clustered in the region spanning codons 746 to 759 within the kinase domain of EGFR. Two types of exon 19 deletions were seen: a 15 nucleotide deletion (del E746-A750) (2 of 70 samples) and a 24 nucleotide deletion (del S752 - 1759) (2 of 70 samples). Other exon 19 mutations observed were the inversion of the complementary strand (1 of 70 samples). Exon 21 mutations included missense substitution, L858R (1 of 70 samples) and T847I (2 of 70 samples). Mutations observed were independent of EGFR protein expression determined by immunohistochemical staining.

Conclusions: This study is among the first to document the presence and estimate the prevalence of EGFR mutations in triple negative breast cancer. These findings have potential implications for the design of clinical trials involving antiEGFR directed therapy which currently do not select for patients based on presence of activating EGFR mutations, which may hence be underpowered to detect significant benefit in unselected populations. More complete sampling of EGFR mutation status in triple negative breast cancer is needed to determine the true mutation rate.

\section{Introduction}

Triple negative breast cancers, defined by the lack of estrogen receptor (ER), progesterone receptor (PR) and epidermal growth factor receptor 2 (Her2/cerbB2/ EGFR2) expression, account for 10 to $20 \%$ of all breast carcinomas in Asian and Western populations [1-7], but

\footnotetext{
* Correspondence: tan.puay.hoon@sgh.com.sg

'Department of Pathology, Singapore General Hospital, Outram Road, Singapore 169608, Singapore

Full list of author information is available at the end of the article
}

occur at much higher frequencies in individuals of African descent $[1-3,8]$. These tumours are usually of higher histological grade (Grade 3) $[1,3,4,6,9,10]$ and are associated with distinctive metastatic patterns $[9,11]$, shorter time to recurrence and earlier mortality $[9,11,12]$. Recent focus on this breast cancer subtype relates to resistance to endocrine and anti-HER2 directed therapy, phenotypic similarity to breast cancers in BRCA1/2 mutation carriers and the development of polyADP-ribose polymerase (PARP) inhibitors which

\section{Biomed Central}

(c) 2011 Teng et al.; licensee BioMed Central Ltd This is an open access article distributed under the terms of the Creative Commons Attribution License (http://creativecommons.org/licenses/by/2.0), which permits unrestricted use, distribution, and reproduction in any medium, provided the original work is properly cited 
have demonstrated promising activity in this disease. Despite this breakthrough, sustained complete remissions in advanced triple negative breast cancer are rare and additional therapies directed against appropriate molecular targets are needed.

EGFR is a receptor tyrosine kinase important in transducing extracellular signals from the cell surface to the cell interior, mediating crucial processes such as cell proliferation, differentiation, migration and apoptosis. Dysregulated expression of these receptors can lead to aberration of homeostatic cellular processes, resulting in malignant transformation of cells. Activating EGFR mutations have been reported in cancers such as non-small cell lung cancer (NSCLC) and head and neck cancers and are predictive of response to gefitinib or erlotinib therapy [13-15]. EGFR protein is expressed in $30 \%$ to $52 \%$ of triple negative breast cancers $[7,16,17]$ and up to $60 \%$ of the closely related basal-like breast cancers and is associated with poor prognosis [18-21]. These observations are the basis for a number of ongoing clinical trials which are exploring the role of monoclonal antibodies against EGFR such as cetuximab and EGFR tyrosine kinase inhibitors such as erlotinib in triple negative breast cancer.

Many mutations in the EGFR gene have been reported in NSCLC but only a few have been validated, either from in vitro studies or from tumour responses in NSCLC patients, to be associated with responses to EGFR tyrosine kinase drugs $[13,14]$. These mutations are usually found in exons 18, 19, 20 and 21, and include missense substitutions such as G719A/S and L858R and deletions like E746 to A750 (removal of amino acids Glucine-LeucineArginine-Glucine-Alanine (ELREA)) which are associated with sensitivity to tyrosine kinase inhibitors [13,14]. Mutations associated with resistance to EGFR tyrosine kinase inhibitors are D761Y [22] and T790M [23,24]. We sought to determine whether such mutations exist in triple negative breast cancers, the results of which may help to select patients suitable for inclusion in clinical trials evaluating the role of anti-EGFR directed therapies in this condition.

In this study, we report that 8 of 70 samples (11.4\%) of triple negative breast cancers harbor EGFR mutations, including exon 19 deletions, inversions and exon 21 missense substitutions, which may predict sensitivity to EGFR tyrosine kinase drugs, thus suggesting a rationale for the clinical applicability of detecting EGFR mutations in these tumours, and potential use of EGFR tyrosine kinase inhibitor therapy.

\section{Materials and methods}

\section{Histopathology and immunohistochemical review}

Seventy archival paraffinised samples of triple negative breast cancer, derived from a cohort of 653 invasive triple negative breast tumours diagnosed at the Department of Pathology, Singapore General Hospital, were chosen for genomic EGFR mutation analysis. Triple negative status of these tumours was confirmed by negative ER, PR, and cerbB2 immunostaining. Briefly, paraffin sections were stained for ER using Neomarker RM9101-S (1:50 dilution), PR using Neomarker RM9102-S (1:200 dilution) and cerbB2 using Neomarker RM9103-S (1:200 dilution). Antigen retrieval was performed by heating in $0.01 \mathrm{M}$ Tris EDTA pH9 using a microwave (Milestone T/T mega). The detection system used was Dako Envision Detection kit (K5007). For the purposes of this study, ER and PR staining was considered positive when at least $10 \%$ of tumour cells displayed a minimum of $2+$ nuclear staining while cerbB2 was considered positive if at least $30 \%$ of tumour cells showed $3+$ cell membrane staining. A borderline/equivocal result was given for cerbB2 when at least $10 \%$ of tumour cells demonstrated $2+$ cytoplasmic membrane staining. Tumours that failed to fulfill any of the above criteria were considered triple negative.

Anti-EGFR monoclonal clone E30 (M7239, Dako, Glostrup, Denmark) was used at a dilution of 1:50. EGFR cytoplasmic membrane positivity was considered positive EGFR staining. Staining intensity was scored as 0 (no staining), $1+$ (weak), 2+ (moderate) and 3+ (strong). The immunohistochemical staining profile of the 653 invasive triple negative breast tumours from which 70 breast tumour tissues used for EGFR mutational analysis were randomly selected from, is shown in Table 1. Ethics approval had been obtained from the Institutional Review Board, Singapore General Hospital. Samples were anonymised with waiver of informed consent.

\section{Mutation analysis}

Representative unstained, formalin-fixed and paraffinembedded (FFPE) tumour sections were macro-dissected to ensure purity of at least $70 \%$ invasive carcinoma cells and without the presence of any normal breast epithelial cells. Genomic DNA was extracted using QIAamp DNA extraction kit for FFPE tissues (Qiagen, Hilden, Germany) according to the manufacturer's protocol but with slight modifications. Briefly, paraffin was removed using xylene and residual xylene removed with ethanol. Buffer ATL was added to the deparaffinised tissue and heated at $98^{\circ} \mathrm{C}$ for 15 minutes $[25,26]$ and cooled to

\begin{tabular}{|c|c|}
\hline EGFR IHC staining & Number of cases (Percentage) \\
\hline Negative (0) & $455(70 \%)$ \\
\hline Weak $(1+)$ & 159 (24\%) \\
\hline Moderate $(2+)$ & $24(4 \%)$ \\
\hline Strong (3+) & $15(2 \%)$ \\
\hline Total & 653 (100\%) \\
\hline
\end{tabular}

IHC, immunohistochemical. 
room temperature. Proteinase $\mathrm{K}$ was then added to the tissue and incubated at $56^{\circ} \mathrm{C}$ for 16 hours. Afterward, the tissue mixture was incubated at $90^{\circ} \mathrm{C}$ for one hour and cooled to room temperature. Buffer AL was then added and the following wash steps were performed according to manufacturer's instructions. DNA yield and purity was quantitated and assessed using the Nanodrop (Thermo Fisher Scientific, Waltham, MA, USA).

Polymerase chain reaction (PCR) was then performed for all DNA samples using primers designed to amplify exons 18, 19, 20 and 21 of the EGFR gene. Primer sequences are shown in Table 2. Amplification reactions were set up using reagents included in the Taq PCR Core Kit (Qiagen), in accordance with the manufacturer's protocol. Essentially, each PCR reaction consisted of $1 \times$ PCR buffer, $0.2 \mathrm{mM}$ dNTP, $0.3 \mathrm{uM}$ forward and reverse primers, $1.25 \mathrm{U}$ Taq DNA polymerase and $250 \mathrm{ng}$ of genomic DNA in a total volume of $50 \mathrm{ul}$. The PCR cycling program was as follows: (1) $94^{\circ} \mathrm{C}$ for 4 minutes $\left(1\right.$ cycle), (2) $94^{\circ} \mathrm{C}$ for 1 minute, $60^{\circ} \mathrm{C}$ for 1 minute, $72^{\circ} \mathrm{C}$ for 1 minute (40 cycles) and $(3) 72^{\circ} \mathrm{C}$ for 10 minutes ( 1 cycle). Nontemplate (DNA) control represented the negative control and was included in every PCR run.

PCR products were analysed by performing electrophoresis on a $2 \%$ agarose gel stained with ethidium bromide. PCR products were purified using Qiagen PCR Purification Kit (Qiagen). The purified PCR amplicons were sequenced by $1^{\text {st }}$ BASE Pte Ltd (Singapore). Sequencing was carried out in both forward and reverse directions. DNA sequences were analysed using the National Center for Biotechnology Information Human EGFR gene sequence (mRNA Reference sequence NM_005228) and BLAST software. EGFR mutations detected in the initial round of sequencing were confirmed by subsequent rounds of independent polymerase chain reaction and sequencing reactions. Only mutations confirmed by subsequent rounds are reported. Cases found to harbor EGFR mutations were checked against the corresponding normal benign breast tissue consisting of at least $50 \%$ of epithelial cells to determine if mutations were somatic or germline.

\section{Results}

\section{Tumour characteristics}

Clinicopathological data for the 70 cases of triple negative breast cancers are shown in Table 3. The median patient age was 57 (range 38 to 78 years) and the patient cohort was predominantly Chinese (59 of 70 cases) with nine patients being of Malay and two patients of Indian ethnicity. Cases were predominantly invasive ductal carcinomas $(n=66)$, with two cases of invasive lobular carcinoma, one case of papillary carcinoma and one metaplastic carcinoma. The majority (53) samples were of histological grade 3 with 15 cases of grade 2 , and two cases which were grade 1 . Sixteen cases showed trabecular growth patterns while the remaining five cases demonstrated syncytial growth. The median tumour size was $34.9 \mathrm{~mm}$ (range $1.5 \mathrm{~mm}$ to $125 \mathrm{~mm}$ ), 28 cases were associated with lymphovascular invasion, and 34 patients had axillary lymph node involvement.

Genomic DNA was extracted from 70 cases of triple negative breast cancers. Successful PCR and good sequencing data were obtained in all samples except 7 samples, 6 samples and 14 samples that failed to amplify for Exon 18, 21 and 20, respectively. EGFR immunohistochemical staining results are shown in Figure 1.

\section{Detection of EGFR mutations}

Several different mutations located in different exons were found in triple negative breast cancer (Table 4). Overall, 8 of 70 cases $(11.4 \%)$ of triple negative breast cancers showed heterozygous exon 19 deletions or exon 21 missense substitution mutations. Notably, 4 of 70 samples (5.8\%) had in-frame deletions in exon 19, where 2 samples (2.9\%) demonstrated 24 bp nucleotide deletions at mRNA coding sequence position 2254 to 2277 , resulting in removal of eight amino acids Serine-Proline-Lysine-Alanine-Asparagine-Lysine-Glutamic acidIsoleucine (SPKANKEI) at codons 752 to 759 (del S752 to I759) (Figure 2A, B) and the other two samples (2.9\%) had a 15 bp nucleotide deletion at mRNA coding sequence positions 2236 to 2250 , with the deletion of five amino acids Glucine-Leucine-Arginine-Glucine-Alanine (ELREA) from codons 746 to 750 (del E746 to A750) (Figure 2C, D). We also observed an exchange of positions of the double strands in the EGFR exon 19 gene, which was accompanied by gene inversion in one sample (Figure 3). Corresponding normal benign breast tissue of all the above cancers harboring mutations did not disclose any abnormalities.

Table 2 Primer sequences

\begin{tabular}{llll}
\hline Exon & Forward Primer & Reverse Primer & PCR product size (bp) \\
\hline Exon 18 & CTGAGGTGACCCTTGTCTCTGTGTTCTT & AGAGGCCTGTGCCAGGGACCTTA & 186 \\
Exon $19[24]$ & TCACTGGGCAGCATGTGGCA & CAGCTGCCAGACATGAGAAA & 241 \\
Exon 20 & CCATGCGAAGCCACACTGA & CGTATCTCCCTTCCCTGATTACC & 248 \\
Exon 21 & AGCAGGGTTTCTCTGTTCA & TGACCTAAAGCCACCTCCTT & 200 \\
\hline
\end{tabular}

$\mathrm{bp}$, base pairs; $\mathrm{PCR}$, polymerase chain reaction. 
Table 3 Clinicopathological characteristics of triple negative breast cancers studied in this cohort

\begin{tabular}{|c|c|}
\hline Clinicopathological features & Numbers \\
\hline \multicolumn{2}{|l|}{ Age (years) } \\
\hline Mean & 52 \\
\hline Minimum & 38 \\
\hline Maximum & 78 \\
\hline \multicolumn{2}{|l|}{ Tumour size (mm) } \\
\hline Mean & $34.9 \mathrm{~mm}$ \\
\hline Minimum & $1.5 \mathrm{~mm}$ \\
\hline Maximum & $125 \mathrm{~mm}$ \\
\hline \multicolumn{2}{|l|}{ Tumour grade } \\
\hline 1 & 2 \\
\hline 2 & 15 \\
\hline 3 & 53 \\
\hline \multicolumn{2}{|l|}{ Histology } \\
\hline Invasive ductal carcinoma & 66 \\
\hline Invasive lobular carcinoma & 2 \\
\hline Papillary & 1 \\
\hline Metaplastic & 1 \\
\hline \multicolumn{2}{|l|}{ Growth pattern } \\
\hline Trabecular & 38 \\
\hline Syncytial & 32 \\
\hline \multicolumn{2}{|l|}{ Nuclear pleomorphism } \\
\hline Moderate & 19 \\
\hline Marked & 51 \\
\hline \multicolumn{2}{|l|}{ Lymphovascular invasion } \\
\hline Present & 28 \\
\hline Absent & 41 \\
\hline Not available & 1 \\
\hline \multicolumn{2}{|l|}{ Axillary lymph node involvement } \\
\hline Involved & 34 \\
\hline Not involved & 31 \\
\hline Not available & 5 \\
\hline \multicolumn{2}{|l|}{ Associated DCIS } \\
\hline Absent & 19 \\
\hline Intermediate nuclear grade & 28 \\
\hline High nuclear grade & 11 \\
\hline Not available & 12 \\
\hline
\end{tabular}

$\mathrm{DCIS}$, ductal carcinoma in situ.

Mutations detected in exon 21 of triple negative breast cancers included two different missense mutations: a T to $G$ substitution at mRNA coding sequence position 2573 resulting in a Leucine to Arginine change at codon 858 (L858R) in $1.5 \%$ of the triple negative breast cancers
(1 of 70 samples) (Figure 4). We also observed a missense substitution of a Threonine residue to an Isoleucine at amino acid codon position 847, resulting from a nucleotide substitution of $\mathrm{C}$ to $\mathrm{T}$ at mRNA coding sequence position 2540 (2 of 70 samples). Similarly, corresponding normal breast tissue of the above three mutated cancer samples showed no mutations, confirming their somatic nature.

Additionally, at exon 18, we found a single nucleotide polymorphism at mRNA coding sequence position 2175 (ACG to ACA) that led to no amino acid changes at codon 725 (Threonine to Threonine) in $4.3 \%$ (3 of 70 samples) of the triple negative breast cancers (T725, NCBI Single Nucleotide Polymorphism database, rs55959834). Also, G to A single nucleotide polymorphism at codon 787 (Glutamine to Glutamine) of exon 20 was found in 6 of the $70(8.6 \%)$ triple negative breast cancers samples (Q787, NCBI Single Nucleotide Polymorphism database, rs1050171). Corresponding normal breast tissues revealed the same polymorphisms as observed in the invasive cancers.

Our study also revealed that triple negative breast tumours harboring EGFR mutations consisted of both EGFR protein positive and negative-stained cases by immunohistochemistry (Table 5).

\section{Discussion}

In this study, we report the presence of EGFR mutations, notably exon 19 deletions and exon 21 missense (L858R) mutations, in $11.8 \%$ of triple negative breast cancers evaluated. All samples showed heterozygous deletions, suggesting they are likely dominant and play a role in tumourigenesis [13]. EGFR mutations have been found to occur in $13 \%$ to $64 \%$ of all non-small cell lung cancers [27] and exon 19 deletions and L858R mutations account for $>80 \%$ of all EGFR mutations detected in NSCLC [27]. More significantly, there is a plethora of studies demonstrating that patients with these exon 19 deletions and L858R mutations respond very well to EGFR inhibitors in NSCLC, as summarized in several reviews [27-29]. Exon 19 deletions and L858R mutations cluster around the ATP-binding pocket of the kinase domain and such mutations confer ligand-independent activation and increased activation duration compared to wild-type receptors $[13,14,30,31]$. In vitro studies showed that exon 19 deleted mutants and L858R mutant receptors appear to be more sensitive to gefitinib inhibition as compared to wild type receptors $[13,14]$. This could explain why NSCLC patients harboring such mutations respond better to EGFR tyrosine kinase inhibitors (TKIs) than patients without such mutations. Patients with exon 19 harboring deletions were found to have longer survival following treatment with gefitinib or erlotinib compared with those having 


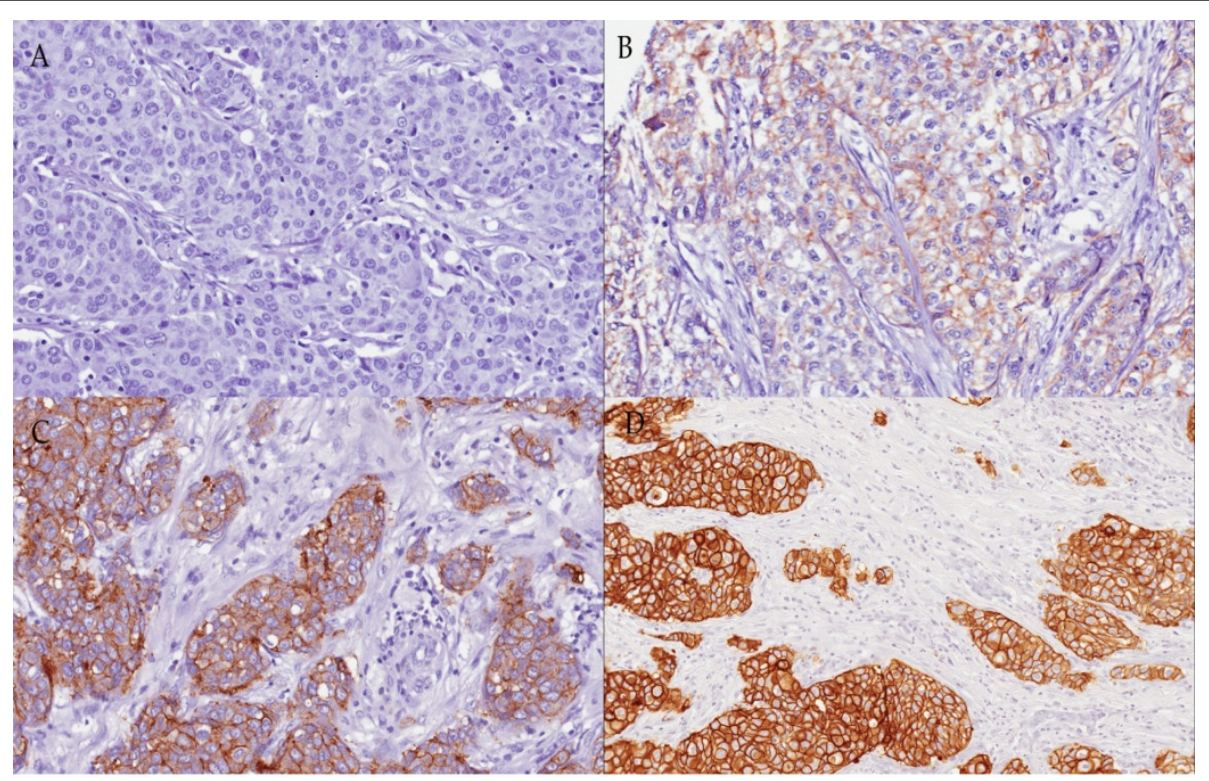

Figure 1 Immunohistochemical staining of EGFR in triple negative breast cancers. (A) Negative EGFR expression (B) 1+ EGFR expression (C) 2+ EGFR expression (D) 3+ EGFR expression.

L858R mutations in NSCLC [32,33]; however, Marks et al. reported no difference in survival between exon 19 deletions and L858R mutations in the absence of EGFR targeted therapy [34].

Several variant types of exon 19 deletions have been reported in NSCLC where the majority (65\% to 75\%) have EGFR exon 19 deletions of the 15 bp type (ELREA) and only a minority ( 1 to $1.5 \%$ ) have 24 bp exon 19 deletions (SPKANKEI) [35]. Conversely, in our triple negative breast cancers, we discovered that both exon 19 type deletions

Table 4 Summary of EGFR mutations detected in primary tumours of triple negative breast cancers $(n=8)$

\begin{tabular}{lc}
\hline Mutations & Number of samples (\%) \\
\hline Exon 19 & \\
del E746 to A750 (15 bp deletion) & $2 / 70(2.9 \%)$ \\
del S752 to I759 (24 bp deletion) & $2 / 70(2.9 \%)$ \\
inversion of complementary strand & $1 / 70(1.5 \%)$
\end{tabular}

Exon 21

L858R

$1 / 70(1.5 \%)$

T847I

$2 / 70(2.9 \%)$

Total

$8 / 70(11.4 \%)$

Single nucleotide polymorphisms

Exon 18

$\mathrm{T} 725 \mathrm{~T}$

$3 / 70(4.3 \%)$

Exon 20

Q787Q

$6 / 70(8.6 \%)$ (del E746 to A750 and del S752 to I759) are seen at similar frequencies. Correlative studies where exon 19 deletions were found to predict good response to EGFR TKIs mainly include the 15 bp deletion type, while 24 bp deletion types were rarely included (probably due to its low frequency) or at best, analysed as a group with the $15 \mathrm{bp}$ deletion mutant. To our best knowledge, there appear to be no reports addressing differing sensitivity of different EGFR exon 19 deletions to gefitinib or erlotinib therapy. Future studies can be done to determine whether there is a variation in sensitivity to EGFR TKIs between the $15 \mathrm{bp}$ deletion type and 24 bp deletion type.

Bhargava et al. reported no EGFR mutations in 11 EGFR-amplified sporadic breast tumours examined, out of which eight tumours were triple negative [36]. In a group of 47 metaplastic breast carcinomas which belonged to a subset of basal-like breast cancers, no EGFR tyrosine kinase mutations were identified as well; however, the actual ER, PR and cerbB2 status of these tumours analysed were not explicitly clarified [21]. Generali et al. also reported no EGFR mutations in 42 sporadic breast tumours (no selection for triple negative breast tumours) [37]. In a study of 58 triple negative breast tumours from Japanese patients, using Taqman genotyping assays against 14 known EGFR mutations including those for exon 19 deletions and L858R missense, EGFR mutations were also not found [38]. However, Weber et al. detected a higher rate of EGFR missense mutations in BRCA1/2 positive tumours (45.8\%) compared with sporadic breast cancers (14.6\%) [39]. BRCA1-linked breast tumours typically exhibit triple negative expression (ER-/PR-/Her2-) [12], 


\section{Forward}

del $\mathrm{S} 752-1759$

(24bp deletion)

del E746-A 750

( $15 \mathrm{bp}$ deletion)
A caacatctccgaangccancanggaatcctcgat

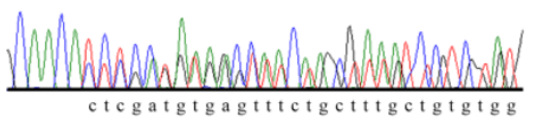

C
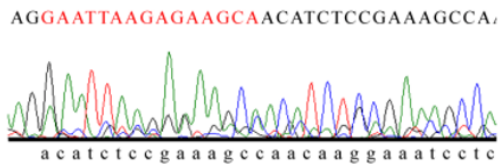

Reverse

$\mathrm{B}$

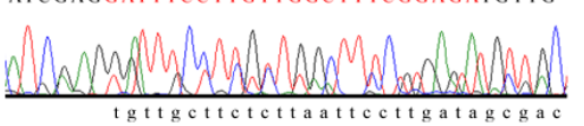

$\mathrm{D}$

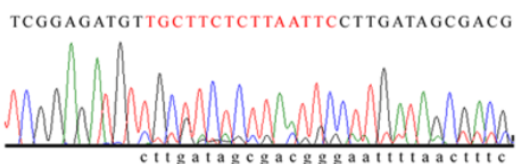

Figure 2 Exon 19 deletions encountered in triple negative breast cancers. Diagrams $\mathbf{A}$ to $\mathbf{D}$ show nucleotide sequences of EGFR gene in triple negative breast tumour specimens with heterozygous in-frame deletions within Exon 19 tyrosine kinase domain (double peaks). Tracings in both $(\mathbf{A}, \mathbf{C})$ sense and $(\mathbf{B}, \mathbf{D})$ antisense directions. The wildtype sequence is shown in capital letters, while the deleted mutant sequence is in lowercase letters. Deleted sequence is highlighted in red capital letters. (A, B) 24 bp deleted region of EGFR gene leading to removal of SPKANKEl at codons 752 to 759. (C, D) 15 bp deleted region of EGFR resulting in deletion of ELREA at codons 746 to 750.

express basal cytokeratins 5 and 6, and EGFR [40-42] and show similar histopathological features to basal-like/triple negative breast cancers [42]. However, EGFR missense mutations identified in the BRCA1/2 tumours were different from those encountered in our triple negative breast cancer study, possibly due to different patient selection where the BRCA1/2 linkage of our study cohort is unknown. The apparent differing findings of the above reports with ours could suggest heterogenous EGFR genomic instability in different breast cancer groups and raises the need for selection of specific breast cancers for EGFR mutation analysis. Different patient ethnicity and backgrounds may also be a contributing factor to the contradictory results seen in our predominantly Chinese cohort with those of the Japanese study group.
The development of anti-EGFR directed therapy in triple negative breast cancer has been supported by the availability of some preclinical data. In vitro studies on effects of EGFR inhibition in triple negative breast cancer cell lines revealed that gefitinib inhibited EGFR phosphorylation, which led to reduced signaling by the mitogen activated protein kinase (MAPK) and Akt pathway and causing cell cycle arrest at G1 phase [43]. In addition, gefitinib enhanced chemotherapeutic response to both carboplatin and docetaxel in these cells [43]. In a Phase II trial of erlotinib in patients with advanced breast cancer, 2 of 69 patients had partial responses, one of which had triplenegative histology [44]. Clinical studies are currently underway to evaluate the efficacy of EGFR tyrosine kinase inhibitors in patients with triple negative breast cancers.

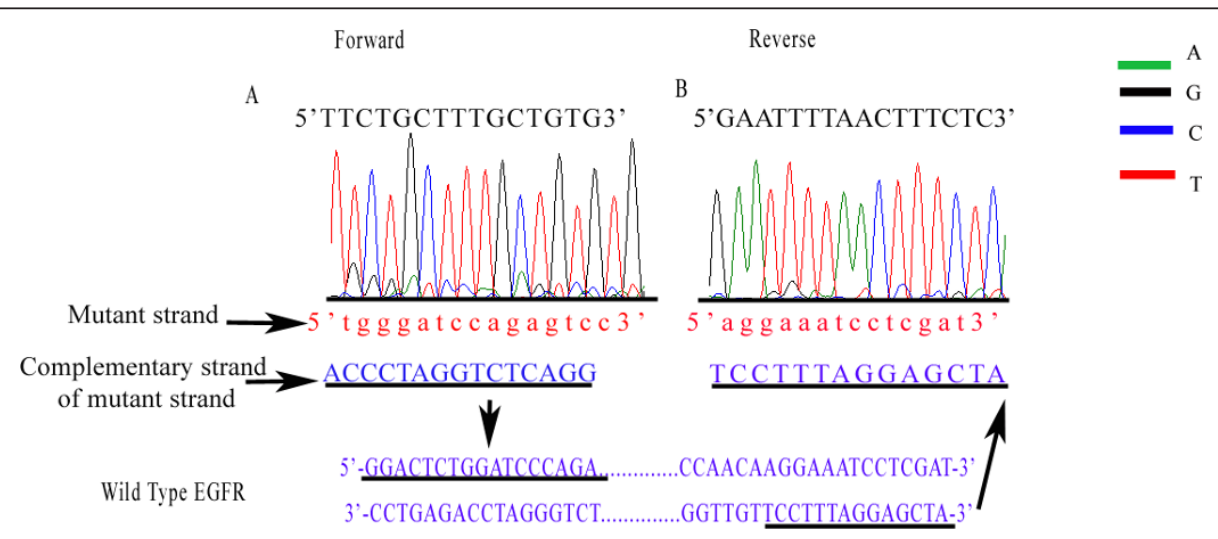

Figure 3 Exchange of positions of double strands in EGFR exon 19, accompanied by gene inversions. Diagrams A and B show nucleotide sequences of EGFR exon 19 gene in triple negative breast tumour specimens with heterozygous gene inversions of the complementary strand (double peaks). Tracings in both (A) sense and (B) antisense directions. The wild type sequence is shown in black capital letters, while the mutant sequence is in red lowercase letters. The complementary sequence of the mutant strand corresponds exactly to the wild type sequence and the orientation is reversed. Note only a segment of the sequencing diagrams (reading sequence towards the end) of the forward and reverse sequence is shown to demonstrate that the whole portion of exon 19 gene is inverted with exchange of the complementary strands. 


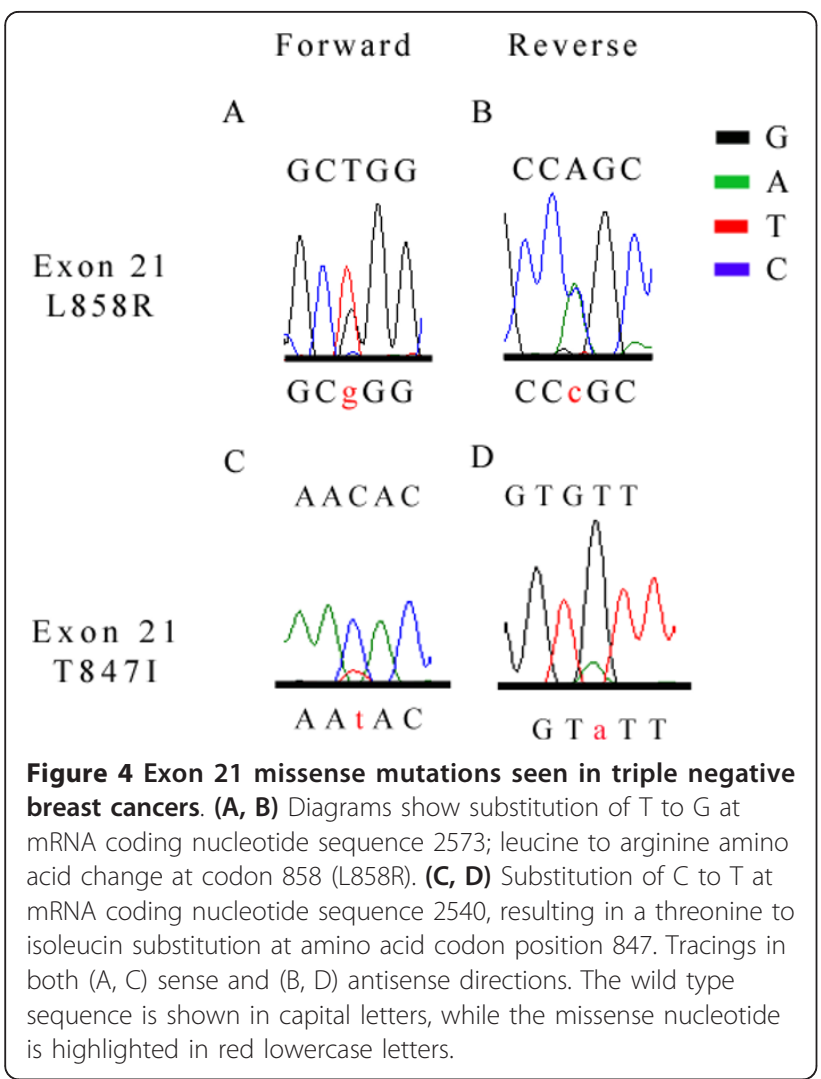

As observed from our study, there is incongruity between EGFR positive immunostaining and the presence of EGFR mutations. It appears that positive EGFR protein expression does not predict the presence of mutations in triple negative breast tumours; conversely, mutations have been found in negative EGFR immunostained breast tumours. Monoclonal antibodies recognize extracellular epitopes of the EGFR and mutations in the

Table 5 EGFR immunostaining scores for 8 samples with EGFR mutations

\begin{tabular}{|c|c|c|}
\hline $\begin{array}{l}\text { Sample } \\
\text { no. }\end{array}$ & $\begin{array}{l}\text { EGFR IHC } \\
\text { score }\end{array}$ & EGFR mutation \\
\hline 1 & 0 & T847I (in frame deletion mutation) \\
\hline 2 & 0 & T847I (in frame deletion mutation) \\
\hline 3 & 0 & $\begin{array}{l}\text { Inversion of complementary strand of } \\
\text { exon } 19\end{array}$ \\
\hline 4 & $3+$ & $\begin{array}{c}\text { Del S752 to } 1759 \text { (In frame deletion } \\
\text { mutation) }\end{array}$ \\
\hline 5 & $2+$ & L858R (Missense mutation) \\
\hline 6 & $1+$ & $\begin{array}{c}\text { Del E746 to A750 (In frame deletion } \\
\text { mutation) }\end{array}$ \\
\hline 7 & $1+$ & $\begin{array}{c}\text { Del E746 to A750 (In frame deletion } \\
\text { mutation) }\end{array}$ \\
\hline 8 & 0 & $\begin{array}{c}\text { Del S752 to } 1759 \text { (In frame deletion } \\
\text { mutation) }\end{array}$ \\
\hline
\end{tabular}

IHC, immunohistochemical.
EGFR gene could confer structural conformational changes that render them unrecognizable by the antibodies; besides, there are also possibilities of mutations in other exons of the EGFR that were not probed in our study. Pinter et al. have described that EGFR mutations in lung adenocarcinomas are not consistently accompanied by EGFR protein positivity by standard immunohistochemistry [45]. They reported that some of the EGFR mutant patients with major clinical response to gefitinib or erlotinib showed negative EGFR immunostaining [45]. Other studies have also noted such disagreement between EGFR immunoexpression and presence of mutations detected via molecular diagnostic methods $[37,46]$. These results suggest the importance of molecular diagnostic methods to identify EGFR mutations and subsequently those who will benefit from EGFR inhibitor therapy. Specific antibodies that can detect EGFR mutants have been developed by Brevet et al., and could be advantageous in early identification of candidates for EGFR mutational analysis via molecular methods in the near future [35].

The relatively small sample size used in this study renders it difficult to make significant statistical judgments. Nevertheless, the identification of important EGFR mutations in our randomly selected cases from the larger series of triple negative breast cancers highlights the need to understand the frequency and type of EGFR mutations in a larger cohort, in order to promote a deeper understanding of the prospective utility of screening for EGFR mutations in relation to the therapeutic use of EGFR tyrosine kinase inhibitors for triple negative breast cancer in a clinical trial setting.

\section{Conclusions}

This study demonstrated existing EGFR mutations in a relatively small study size of 70 triple negative breast cancers in a Singapore population (8 of 70 samples). Mutations observed included EGFR exon 19 deletions (4 of 70 samples ) and EGFR exon 21 substitutions (3 of 70 samples), both of which are commonly found in NSCLC and are good predictors of sensitivity to tyrosine kinase inhibition therapy. This advocates the promising application of gefitinib or erlotinib therapy in triple negative breast cancer, where the need to find new tailored treatment is critical. These findings also encourage larger scale prospective trials to evaluate the need for EGFR mutation screening for anti-EGFR treatment in triple negative breast cancers. It is also apparent that EGFR positivity by standard immunohistochemistry is not necessarily accompanied by EGFR mutations, suggesting that molecular diagnostic methods appear to be more important for selection of potential prospective patients with triple negative breast cancers who may benefit from EGFR inhibitor therapy. 


\section{Abbreviations}

Bp: base pairs; cerbB2: epidermal growth factor receptor 2; DNA: deoxyribonucleic acid; EGFR: epidermal growth factor receptor; ELREA: amino acids Glucine-Leucine-Arginine-Glucine-Alanine; ER: estrogen receptor; FFPE: formalin-fixed and paraffin-embedded; IDC: invasive ductal carcinoma; ILC: invasive lobular carcinoma; MAPK: mitogen activated protein kinase; NSCLC: non-small cell lung cancer; PCR: polymerase chain reaction; PARP: polyADPribose polymerase; PR: progesterone receptor; SPKANKEI: amino acids SerineProline-Lysine-Alanine-Asparagine-Lysine-Glutamic acid-Isoleucine; TKIs: tyrosine kinase inhibitors.

\section{Acknowledgements}

This work was supported by a grant from the Singapore Cancer Syndicate (MS04R) to PH Tan.

\section{Author details}

${ }^{1}$ Department of Pathology, Singapore General Hospital, Outram Road, Singapore 169608, Singapore. ${ }^{2}$ Department of Anatomical and Cellular Pathology, Chinese University of Hong Kong, Ngan Shing Street, Shatin, NT, SAR, PR China. ${ }^{3}$ Department of Medical Oncology, National Cancer Centre Singapore, 11 Hospital Drive, Singapore 169610, Singapore. ${ }^{4}$ Department of Anatomy, Yong Loo Lin School of Medicine, National University of Singapore, MD10, 4 Medical Drive, Singapore 117597, Singapore.

\section{Authors' contributions}

YHFT participated in the design of the study, DNA extraction, PCR, analysis of DNA mutations and writing of the manuscript. WJT participated in DNA extraction, PCR, analysis of DNA mutations and writing of the manuscript. AAT participated in the design of the study, analysis of EGFR immunoscoring, and writing of the manuscript. PYC participated in EGFR immunostaining, DNA extraction and writing of the manuscript. GMKT, BHB, GWCY and NSW contributed to the scientific content and participated in writing the manuscript. PHT conceived the study, designed and coordinated all experiments and was involved in writing of the manuscript. All authors read and approved the final manuscript.

\section{Competing interests}

The authors declare that they have no competing interests.

Received: 21 June 2010 Revised: 26 December 2010

Accepted: 1 April 2011 Published: 1 April 2011

\section{References}

1. Lund MJ, Trivers KF, Porter PL, Coates RJ, Leyland-Jones B, Brawley OW, Flagg EW, O'Regan RM, Gabram SG, Eley JW: Race and triple negative threats to breast cancer survival: a population-based study in Atlanta, GA. Breast Cancer Res Treat 2009, 113:357-370.

2. Bauer KR, Brown M, Cress RD, Parise CA, Caggiano V: Descriptive analysis of estrogen receptor (ER)-negative, progesterone receptor (PR)-negative, and HER2-negative invasive breast cancer, the so-called triple-negative phenotype: a population-based study from the California Cancer Registry. Cancer 2007, 109:1721-1728.

3. Morris GJ, Naidu S, Topham AK, Guiles F, Xu Y, McCue P, Schwartz GF, Park PK, Rosenberg AL, Brill K, Mitchell EP: Differences in breast carcinoma characteristics in newly diagnosed African-American and Caucasian patients. Cancer 2007, 110:876-884.

4. Rhee J, Han SW, Oh DY, Kim JH, Im SA, Han W, Park IA, Noh DY, Bang YJ, Kim TY: The clinicopathologic characteristics and prognostic significance of triple-negativity in node-negative breast cancer. BMC Cancer 2008, 8:307.

5. Iwase H, Kurebayashi J, Tsuda H, Ohta T, Kurosumi M, Miyamoto K, Yamamoto $Y$, Iwase $T$ : Clinicopathological analyses of triple negative breast cancer using surveillance data from the Registration Committee of the Japanese Breast Cancer Society. Breast Cancer 2010, 17:118-124.

6. Yin WJ, Lu JS, Di GH, Lin YP, Zhou LH, Liu GY, Wu J, Shen KW, Han QX, Shen ZZ, Shao ZM: Clinicopathological features of the triple-negative tumours in Chinese breast cancer patients. Breast Cancer Res Treat 2009, 115:325-333.

7. Thike AA, Cheok PY, Jara-Lazaro AR, Tan B, Tan P, Tan PH: Triple-negative breast cancer: clinicopathological characteristics and relationship with basal-like breast cancer. Mod Pathol 2010, 23:123-133.
8. Huo D, Ikpatt F, Khramtsov A, Dangou JM, Nanda R, Dignam J, Zhang B, Grushko T, Zhang C, Oluwasola O, Malaka D, Malami S, Odetunde A, Adeoye AO, lyare F, Falusi A, Perou CM, Olopade Ol: Population differences in breast cancer: survey in indigenous African women reveals over-representation of triple-negative breast cancer. J Clin Oncol 2009, 27:4515-4521.

9. Dent R, Trudeau M, Pritchard Kl, Hanna WM, Kahn HK, Sawka CA, Lickley LA, Rawlinson E, Sun P, Narod SA: Triple-negative breast cancer: clinical features and patterns of recurrence. Clin Cancer Res 2007, 13:4429-4434.

10. Livasy CA, Karaca G, Nanda R, Tretiakova MS, Olopade Ol, Moore DT, Perou CM: Phenotypic evaluation of the basal-like subtype of invasive breast carcinoma. Mod Pathol 2006, 19:264-271.

11. Banerjee S, Reis-Filho JS, Ashley S, Steele D, Ashworth A, Lakhani SR, Smith IE: Basal-like breast carcinomas: clinical outcome and response to chemotherapy. J Clin Pathol 2006, 59:729-735.

12. Haffty BG, Yang Q, Reiss M, Kearney T, Higgins SA, Weidhaas J, Harris L, Hait W, Toppmeyer D: Locoregional relapse and distant metastasis in conservatively managed triple negative early-stage breast cancer. J Clin Oncol 2006, 24:5652-5657.

13. Lynch TJ, Bell DW, Sordella R, Gurubhagavatula S, Okimoto RA, Brannigan BW, Harris PL, Haserlat SM, Supko JG, Haluska FG, Louis DN, Christiani DC, Settleman J, Haber DA: Activating mutations in the epidermal growth factor receptor underlying responsiveness of nonsmall-cell lung cancer to gefitinib. N Engl J Med 2004, 350:2129-2139.

14. Paez JG, Janne PA, Lee JC, Tracy S, Greulich H, Gabriel S, Herman P, Kaye FJ, Lindeman N, Boggon TJ, Naoki K, Sasaki H, Fujii Y, Eck MJ, Sellers WR, Johnson BE, Meyerson M: EGFR mutations in lung cancer: correlation with clinical response to gefitinib therapy. Science 2004, 304:1497-1500.

15. Lee JW, Soung YH, Kim SY, Nam HK, Park WS, Nam SW, Kim MS, Sun DI, Lee YS, Jang JJ, Lee JY, Yoo NJ, Lee SH: Somatic mutations of EGFR gene in squamous cell carcinoma of the head and neck. Clin Cancer Res 2005, 11:2879-2882

16. Rakha EA, El-Sayed ME, Green AR, Lee AH, Robertson JF, Ellis IO: Prognostic markers in triple-negative breast cancer. Cancer 2007, 109:25-32

17. Pintens $S$, Neven $P$, Drijkoningen $M$, Van Belle V, Moerman $P$, Christiaens MR, Smeets A, Wildiers H, Vanden Bempt I: Triple negative breast cancer: a study from the point of view of basal CK5/6 and HER-1. J Clin Pathol 2009, 62:624-628.

18. Lerma E, Peiro G, Ramon T, Fernandez S, Martinez D, Pons C, Munoz F, Sabate JM, Alonso C, Ojeda B, Prat J, Barnadas A: Immunohistochemical heterogeneity of breast carcinomas negative for estrogen receptors, progesterone receptors and Her2/neu (basal-like breast carcinomas). Mod Pathol 2007, 20:1200-1207.

19. Nielsen TO, Hsu FD, Jensen K, Cheang M, Karaca G, Hu Z, HernandezBoussard T, Livasy C, Cowan D, Dressler L, Akslen LA, Ragaz J, Gown AM, Gilks CB, van de Rijn M, Perou CM: Immunohistochemical and clinical characterization of the basal-like subtype of invasive breast carcinoma. Clin Cancer Res 2004, 10:5367-5374.

20. Viale G, Rotmensz N, Maisonneuve P, Bottiglieri L, Montagna E, Luini A, Veronesi P, Intra M, Torrisi R, Cardillo A, Campagnoli E, Goldhirsch A Colleoni M: Invasive ductal carcinoma of the breast with the "triplenegative" phenotype: prognostic implications of EGFR immunoreactivity. Breast Cancer Res Treat 2009, 116:317-328.

21. Reis-Filho JS, Pinheiro C, Lambros MB, Milanezi F, Carvalho S, Savage K, Simpson PT, Jones C, Swift S, Mackay A, Reis RM, Hornick JL, Pereira EM, Baltazar F, Fletcher CD, Ashworth A, Lakhani SR, Schmitt FC: EGFR amplification and lack of activating mutations in metaplastic breast carcinomas. J Pathol 2006, 209:445-453.

22. Balak MN, Gong Y, Riely GJ, Somwar R, Li AR, Zakowski MF, Chiang A, Yang G, Ouerfelli O, Kris MG, Ladanyi M, Miller VA, Pao W: Novel D761Y and common secondary T790M mutations in epidermal growth factor receptor-mutant lung adenocarcinomas with acquired resistance to kinase inhibitors. Clin Cancer Res 2006, 12:6494-6501.

23. Kobayashi S, Boggon TJ, Dayaram T, Janne PA, Kocher O, Meyerson M, Johnson BE, Eck MJ, Tenen DG, Halmos B: EGFR mutation and resistance of non-small-cell lung cancer to gefitinib. N Engl J Med 2005, 352:786-792.

24. Pao W, Miller VA, Politi KA, Riely GJ, Somwar R, Zakowski MF, Kris MG, Varmus $\mathrm{H}$ : Acquired resistance of lung adenocarcinomas to gefitinib or erlotinib is associated with a second mutation in the EGFR kinase domain. PLoS Med 2005, 2:e73. 
25. Gilbert MT, Haselkorn T, Bunce M, Sanchez JJ, Lucas SB, Jewell LD, Van Marck E, Worobey M: The isolation of nucleic acids from fixed, paraffinembedded tissues-which methods are useful when? PLoS One 2007, 2 : e537.

26. Wu L, Patten N, Yamashiro CT, Chui B: Extraction and amplification of DNA from formalin-fixed, paraffin-embedded tissues. Appl Immunohistochem Mol Morphol 2002, 10:269-274.

27. Linardou H, Dahabreh IJ, Bafaloukos D, Kosmidis P, Murray S: Somatic EGFR mutations and efficacy of tyrosine kinase inhibitors in NSCLC. Nat Rev Clin Oncol 2009, 6:352-366.

28. Sharma SV, Bell DW, Settleman J, Haber DA: Epidermal growth factor receptor mutations in lung cancer. Nat Rev Cancer 2007, 7:169-181.

29. Yamamoto $H$, Toyooka S, Mitsudomi T: Impact of EGFR mutation analysis in non-small cell lung cancer. Lung Cancer 2009, 63:315-321.

30. Amann J, Kalyankrishna S, Massion PP, Ohm JE, Girard L, Shigematsu H, Peyton M, Juroske D, Huang Y, Stuart Salmon J, Kim YH, Pollack JR, Yanagisawa K, Gazdar A, Minna JD, Kurie JM, Carbone DP: Aberrant epidermal growth factor receptor signaling and enhanced sensitivity to EGFR inhibitors in lung cancer. Cancer Res 2005, 65:226-235.

31. Pao W, Miller V, Zakowski M, Doherty J, Politi K, Sarkaria I, Singh B, Heelan R, Rusch V, Fulton L, Mardis E, Kupfer D, Wilson R, Kris M, Varmus H: EGF receptor gene mutations are common in lung cancers from "never smokers" and are associated with sensitivity of tumours to gefitinib and erlotinib. Proc Natl Acad Sci USA 2004, 101:13306-13311.

32. Riely GJ, Pao W, Pham D, Li AR, Rizvi N, Venkatraman ES, Zakowski MF, Kris MG, Ladanyi M, Miller VA: Clinical course of patients with non-small cell lung cancer and epidermal growth factor receptor exon 19 and exon 21 mutations treated with gefitinib or erlotinib. Clin Cancer Res 2006, 12:839-844.

33. Jackman DM, Yeap BY, Sequist LV, Lindeman N, Holmes AJ, Joshi VA, Bell DW, Huberman MS, Halmos B, Rabin MS, Haber DA, Lynch TJ, Meyerson M, Johnson BE, Janne PA: Exon 19 deletion mutations of epidermal growth factor receptor are associated with prolonged survival in non-small cell lung cancer patients treated with gefitinib or erlotinib. Clin Cancer Res 2006, 12:3908-3914.

34. Marks JL, Broderick S, Zhou Q, Chitale D, Li AR, Zakowski MF, Kris MG, Rusch WW, Azzoli CG, Seshan VE, Ladanyi M, Pao W: Prognostic and therapeutic implications of EGFR and KRAS mutations in resected lung adenocarcinoma. J Thorac Oncol 2008, 3:111-116.

35. Brevet $M$, Arcila M, Ladanyi M: Assessment of EGFR mutation status in lung adenocarcinoma by immunohistochemistry using antibodies specific to the two major forms of mutant EGFR. J Mol Diagn 2010, 12:169-176.

36. Bhargava R, Gerald WL, Li AR, Pan Q, Lal P, Ladanyi M, Chen B: EGFR gene amplification in breast cancer: correlation with epidermal growth factor receptor mRNA and protein expression and HER-2 status and absence of EGFR-activating mutations. Mod Pathol 2005, 18:1027-1033.

37. Generali D, Leek R, Fox SB, Moore JW, Taylor C, Chambers P, Harris AL: EGFR mutations in exons 18-21 in sporadic breast cancer. Ann Oncol 2007, 18:203-205.

38. Toyama T, Yamashita H, Kondo N, Okuda K, Takahashi S, Sasaki H, Sugiura $H$, Iwase $H$, Fujii $Y$ : Frequently increased epidermal growth factor receptor (EGFR) copy numbers and decreased BRCA1 mRNA expression in Japanese triple-negative breast cancers. BMC Cancer 2008, 8:309.

39. Weber F, Fukino K, Sawada T, Williams N, Sweet K, Brena RM, Plass C, Caldes T, Mutter GL, Villalona-Calero MA, Eng C: Variability in organspecific EGFR mutational spectra in tumour epithelium and stroma may be the biological basis for differential responses to tyrosine kinase inhibitors. Br J Cancer 2005, 92:1922-1926.

40. Foulkes WD, Brunet JS, Stefansson IM, Straume O, Chappuis PO, Begin LR, Hamel N, Goffin JR, Wong N, Trudel M, Kapusta L, Porter P, Akslen LA: The prognostic implication of the basal-like (cyclin E high/p27 low/p53 +/glomeruloid-microvascular-proliferation+) phenotype of BRCA1-related breast cancer. Cancer Res 2004, 64:830-835.

41. Foulkes WD, Stefansson IM, Chappuis PO, Begin LR, Goffin JR, Wong N, Trudel M, Akslen LA: Germline BRCA1 mutations and a basal epithelial phenotype in breast cancer. J Natl Cancer Inst 2003, 95:1482-1485.

42. Honrado E, Benitez J, Palacios J: Histopathology of BRCA1- and BRCA2associated breast cancer. Crit Rev Oncol Hematol 2006, 59:27-39.
43. Corkery B, Crown J, Clynes M, O'Donovan N: Epidermal growth factor receptor as a potential therapeutic target in triple-negative breast cancer. Ann Oncol 2009, 20:862-867.

44. Dickler MN, Cobleigh MA, Miller KD, Klein PM, Winer EP: Efficacy and safety of erlotinib in patients with locally advanced or metastatic breast cancer. Breast Cancer Res Treat 2009, 115:115-121.

45. Pinter F, Papay J, Almasi A, Sapi Z, Szabo E, Kanya M, Tamasi A, Jori B, Varkondi E, Moldvay J, Szondy K, Keri G, Dominici M, Conte P, Eckhardt S, Kopper L, Schwab R, Petak I: Epidermal growth factor receptor (EGFR) high gene copy number and activating mutations in lung adenocarcinomas are not consistently accompanied by positivity for EGFR protein by standard immunohistochemistry. J Mol Diagn 2008, 10:160-168.

46. Willmore-Payne C, Holden JA, Layfield LJ: Detection of epidermal growth factor receptor and human epidermal growth factor receptor 2 activating mutations in lung adenocarcinoma by high-resolution melting amplicon analysis: correlation with gene copy number, protein expression, and hormone receptor expression. Hum Pathol 2006 , 37:755-763.

doi: $10.1186 / \mathrm{bcr} 2857$

Cite this article as: Teng et al:: Mutations in the epidermal growth factor receptor (EGFR) gene in triple negative breast cancer: possible implications for targeted therapy. Breast Cancer Research 2011 13:R35.

\section{Submit your next manuscript to BioMed Central and take full advantage of:}

- Convenient online submission

- Thorough peer review

- No space constraints or color figure charges

- Immediate publication on acceptance

- Inclusion in PubMed, CAS, Scopus and Google Scholar

- Research which is freely available for redistribution

Submit your manuscript at www.biomedcentral.com/submit
Biomed Central 